ISSN: 1979-7362

\title{
Pengaruh Sifat Fisik Tanah dan Sistem Perakaran Vegetasi Terhadap Imbuhan Air Tanah
}

\author{
Andi Musdalipa ${ }^{1}$, Suhardi $^{1}$ dan Sitti Nur Faridah ${ }^{1}$ \\ ${ }^{1)}$ Program Studi Teknik Pertanian, Universitas Hasanuddin Makassar
}

\begin{abstract}
ABSTRAK
Infiltrasi merupakan suatu proses masuknya air kedalam tanah secara vertikal melalui permukaan tanah yang tergantung kepada karakteristik tanah dan perakaran vegetasi. Oleh karena itu, dalam pengujian infiltrasi pada suatu lahan pertanian perlu dilakukan identifikasi karakteristik tanah (tekstur) dan karakteristik perakaran vegetasi. Tujuan penelitian ini adalah untuk mengetahui pengaruh akar vegetasi dan tekstur tanah terhadap laju infiltrasi. Untuk menentukan hubungan antara vegetasi terhadap laju infiltrasi dilakukan pengukuran tekstur tanah, kadar air, berat akar vegetasi, dan proses terjadinya laju infiltrasi masing-masing sampel yang dilakukan dalam empat kali pengujian. Berdasarkan data yang diperoleh, besarnya pengaruh vegetasi terhadap laju infiltrasi yang dipengaruhi oleh sifat fisik tanah dapat dilihat pada hasil yang didapatkan. Data untuk tekstur tanah cenderung berpasir untuk masing-masing sampel yaitu 90,3\%, 96,2\%, $96,0 \%$, dan 84,5\%. Hal tersebut berpengaruh teradap laju infiltrasi karena semakin besar pori-pori tanah maka laju infiltrasi ketanah juga semakin cepat. Sedangkan pada berat akar vegetasi masing-masing nilainya adalah 1,5 $\mathrm{g}$ (sampel I), 1,8 $\mathrm{g}$ (sampel II), 1,7 g (sampel III), dan 1,3 g (sampel IV). Dari data pengukuran akar vegetasi jika dihubungkan dengan laju infiltrasi menunjukkan bahwa semakin berat akar vegetasi maka proses laju infiltrasi akan semakin cepat dan pengisian air tanah akan semakin tinggi. Berdasarkan penelitian yang dilakukan dapat disimpulkan bahwa pengaruh sifat fisik tanah dan sistem perakaran vegetasi sangat mempengaruhi proses terjadinya laju infiltrasi.
\end{abstract}

Kata kunci: infiltrasi, vegetasi, tekstur tanah, air tanah.

\section{PENDAHULUAN}

\section{Latar Belakang}

Air dan tanah merupakan komponen penting dan banyak berperan dalam proses kehidupan di muka bumi ini. Hubungan antar keduanya sangat erat sekali, pada musim hujan air jatuh dari langit kemudian masuk ke dalam tanah sehingga terjadi pergerakan air di dalam tanah yang disebut dengan infiltrasi.

Infiltrasi merupakan suatu proses masuknya air ke dalam tanah secara vertikal melalui permukaan tanah dan kemampuan sistem lahan dalam merentansi air hujan sangat tergantung kepada karakteristik sistem tajuk dan perakaran tipe vegetasi. Sistem tata guna lahan dengan vegetasi penutup tanah merupakan sistem lahan yang mempunyai kemampuan merentansi air hujan lebih baik dari pada sistem lahan tingkat semai/semak atau tiang. Dengan demikian vegetasi mempunyai fungsi yang lebih baik untuk meningkatkan laju infiltrasi dan menyimpan air (Suharto, 2006)

Intensitas cura hujan yang tinggi dapat menghancurkan dan mendisfersikan agregat tanah sehingga menyebabkan penyumbatan pori tanah di permukaan yang berpengaruh terhadap tekstur tanah akan menurunkan laju infiltrasi. Vegetasi penutupan lahan kemungkinan tidak akan tumbuh dengan kondisi lahan yang memiliki tekstur dengan pori yang lebih kecil, begitupun sebaliknya. Maka dari itu, infiltrasi dapat dipakai untuk menentukan 
besarnya pengisian kembali (recharge) air tanah yang bermanfaat untuk pertumbuhan dan produksi tanaman, untuk menghitung limpasan permukaan (run off), serta dalam pengelolaan air irigasi di bidang pertanian. Perubahan penggunaan lahan dan perbedaan sifat-sifat tanah yang meliputi alih fungsi lahan yang semula ada vegetasi menjadi lahan yang tak ada atau minim vegetasi mengakibatkan laju infiltrasi dan perkolasi pada tanah menjadi berubah (Elsa, 2013).

Berdasarkan uraian di atas, untuk menjelaskan hubungan antara infiltrasi dengan vegetasi serta tekstur tanah dengan vegetasi maka perlu dilakukan penelitian untuk mengetahui pengaruh perakaran vegetasi terhadap pertambahan air tanah serta sifat fisik tanah

\section{Tujuan dan kegunaan}

Tujuan dari penelitian ini adalah untuk mengetahui pengaruh akar rumput, kadar air tanah dan pengaruh sistem perakaran vegetasi terhadap laju infiltrasi.

Kegunaan dari penelitian ini sebagai sumber informasi dalam proses penentuan jenis tanaman

\section{METODELOGI}

\section{Waktu dan Tempat}

Penelitian ini dilaksanakan pada bulan Mei 2017 di Experimental Farming (Exfarm), dan Laboratorium Mekanika Fliuda, Fakultas Pertanian, Universitas Hasanuddin

\section{Alat dan Bahan \\ Alat yang digunakan pada penelitian pengaruh perakaran vegetasi terhadap penyerapan air tanah di Experimental Farming (Ex-Farm) yaitudengan menggunakan, infiltrometer, ring sampel, timbangan digital, oven, meteran, gelas ukur, pipet ukur, botol semprot, cawan petri, pengocok/miixer, hydrometer dan thermometer. \\ Sedangkan bahan yang digunakan pada penelitian ini adalah tanah, akar rumput,}

air, larutan pendispersi natrium pirosposfat, $30 \% \mathrm{H}_{2} \mathrm{O}_{2}$, sodium hexa meta fosfat $\left(\mathrm{NaPO}_{3}\right)_{6} 10 \%$, aseton, air suling dan plastik sampel.

\section{Prosedur Penelitian}

Prosedur penelitian dapat dilihat pada diagram alir di bawah ini yang menggambarkan tentang proses pengambilan sampel.

\section{Bagan Alir Penelitian}

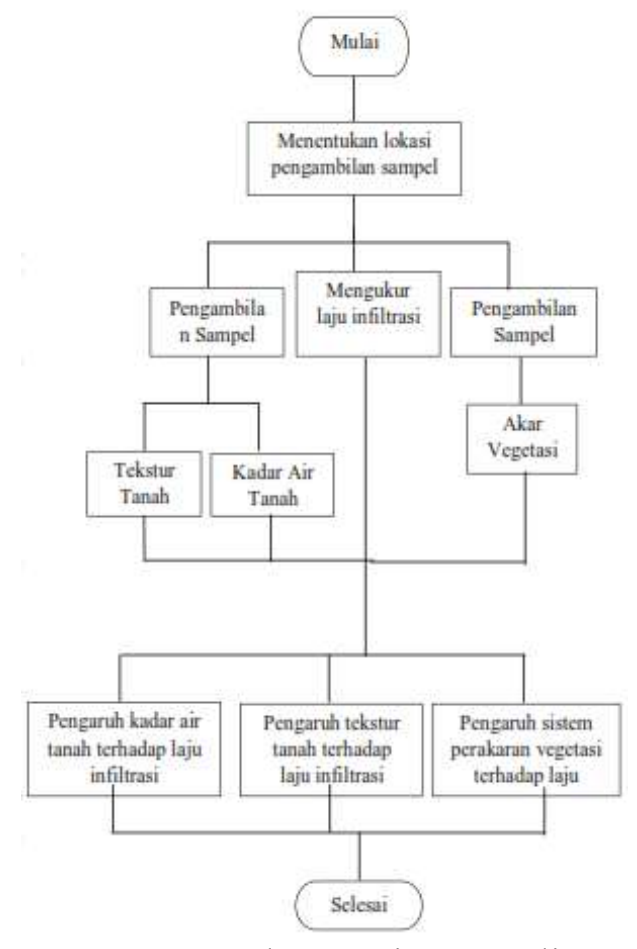

Gambar 1. Diagram Alir

\section{HASIL DAN PEMBAHASAN}

\section{Penentuan Tekstur Tanah}

Penentuan tekstur tanah dapat dilakukan dengan berbagai metode. Metode yang biasa digunakan, yaitu metode hydrometer, metode pipet, dan metode langsung. Namun, pada pengujian kali ini menggunakan metode hydrometer. Hydrometer merupakan alat ukur berat jenis atau kepadatan relatif dari cairan seperti rasio densitas dan cairan kepadatan air. Hasil pengujian tekstur tanah dapat dilihat pada Tabel 1 berikut: 
Tabel 1. Fraksi tanah berdasarkana klasifikasi pengujian tekstur tanah

\begin{tabular}{lc}
\hline Sampel & Persentase Fraksi (\%) \\
\hline PasirDebuLiat \\
\hline
\end{tabular}

190.32.17.7

II 96.20 .83 .0

III 96.00 .53 .5

IV84.53.212.3

Pengujian sampel tanah yang dilakukan sebanyak empat kali pengulangan dari empat sampel tanah pada lahan pengambilan sampel yang sama. Namun, titik pengambilan sampel yang dibedakan dapat dilihat pada data yang dihasilkan bahwa setiap sampel memiliki hasil fraksi yang tidak jauh berbeda.Persentase fraksi yang dihasilkan menunjukkan fraksi pasir untuk sampel 13 dan untuk sampel ke-4 termasuk tekstur tanah pasir berlempung.Maka dari itu, jenis tanah yang diuji cenderung berpasir.Hal ini sesuai dengan pendapat Arifin (2010), bahwa tanah bertekstur pasir yaitu tanah dengan kandungan pasir $>70$ $\%$.Dengan melihat persentase setiap fraksi yang dihasilkan, maka volume pori tanah sangat besar karena memiliki fraksi pasir yang tinggi sehingga proses terjadinya laju infiltrasi semakin besar. Hal ini sesuai dengan pendapat Rahim (2003), bahwa semakin besar volume pori tanah, dan semakin remah tanahnyamaka laju infiltrasi akan semakin besar. Proses penyerapan air tanah atau yang disebut dengan laju infiltrasi sangat dipengaruhi oleh jenis tanah yang didapatkan dilahan, oleh sebab itu pengujian tekstur sangat diperlukan dalam proses penentuan laju infiltrasi dimana begitu banyak jenis tanah yang berbeda-beda. Tanah yang sama akan tetapi kepadatanya berbeda maka akan terjadi perbedaan proses laju infiltrasi. Hal ini di sebabkan oleh tanah yang mengandung pasir sangat cepat proses penyerapan air tanh dibandingkan dengan tanah yang mengandung debu dan liat. Hal ini sesuai dengan pendapat Jati (2015) bahwa untuk satu jenis tanah yang sama dengan kepadatan yang berbeda mempunyai laju infiltrasi yang berbeda pula, semakin padat maka semakin kecil laju infiltrasinya. Pengujian tekstur tanah berhubungan erat terhadap laju infiltrasi yang sangat dibutuhkan sebagai informansi dalam proses penanaman yang dilakukan atau dalam proses penentuan tanaman, tekstur tanah yang berbeda mengakibatkan tanah memilki unsur hara yang berbeda pula yang dipengaruhi oleh pertambahan air tanah yang terjadi akibat proses laju infiltrasi sehingga jenis tanaman yang dibutuhkan juga berbeda.

\section{Laju Infiltrasi Pada Setiap Sampel} Tanah Dengan Kadar Air Berbeda

Penentuan kadar air tanah sangat dibutuhkan dalam proses penanaman. Oleh karena itu perlu dilakukan pengukuran kadar air tanah di laboratorium. Pada pengukuran ini digunakan empat sampel tanah dengan titik pengambilan sampel yang berbeda dengan menggunakan ring sampel. Hasil pengukuran dapat dilihat pada Gambar 2.

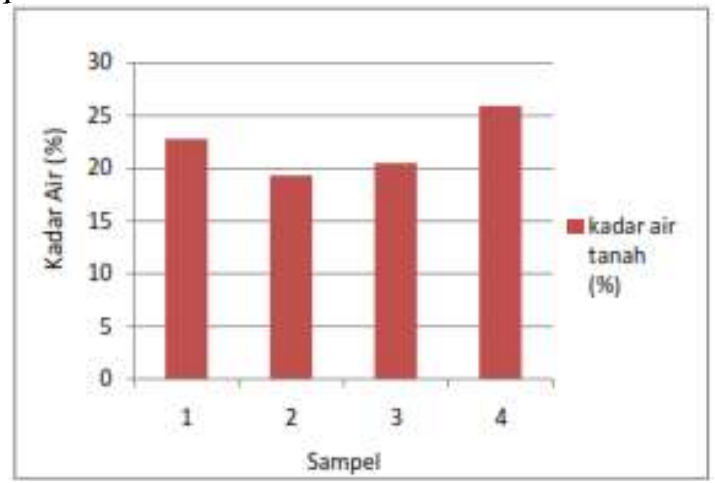

Gambar 2. Pengukuran Kadar Air Tanah Awal

Kadar air tanah merupakan pengisian kedalaman air yang terdapat pada volume tanah yang sangat dibutuhkan sebagai acuan informasi dalam proses penentuan tanaman. Hal ini sesuai pendapat Hakim (2000) bahwa kadar air tanah Alfisol dapat dinyatakan dalam persen volume yaitupersentase volume air terhadap 
volume tanah. Cara ini mempunyai keuntungan karena dapat memberikan gambaran tentang ketersediaan air bagi tanaman pada volume tanah tertentu.Hasil yang didapatkan pada pengujian kadar air tanah memiliki nilai yang berbeda setiap sampel pengujian yang dilakukan meski memiliki berat awal yang sama, air yang hilang pada saat melakukan pengovenan merupakan bagian dari kadar air tanah. Hal ini sesuai pendapat Hakim (2000) bahwa air yang hilang karena pengeringan merupakan sejumlah air yang terkandung dalam tanahtersebut. Sehingga data yang didapatkan memiliki kadar air yang berbeda meski memiliki berat sampel yang sama. Kadar air tanah sangat dipengaruhi oleh proses laju infiltrasi, pengaruh kadar air tanah terhadap laju infiltrasi dengan menggunakan metode R-squared polynomial dapat dilihat pada Gambar 3.

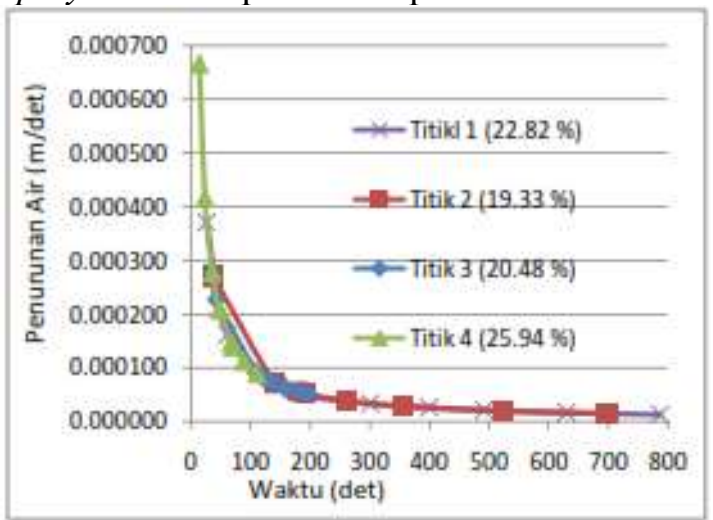

Gambar 3. Laju infiltrasi pada setiap sampel tanah dengan kadar air berbeda

Berdasarkan data pengujian antara kadar air tanah dan laju infiltrasi menunjukkan hubungan yang berbanding lurus. Data yang diperoleh dari pengolahan sampel ke-4 memiliki kadar air yang cukup tinggi sehingga akan mempengaruhi kelembaban pada struktur tanah, tanah yang memiliki kelembaban kecil akan mempengaruhi laju infiltrasi sehingga mengalami peningkatan. Hal tersebut juga dapat mempengaruhi kadar air. Semakin tinggi laju infiltrasi maka kadar air tanah semakin kecil. Hal ini sesuai pendapat Agung (2010) bahwalaju infiltrasi pada tanah semakin lama semakin kecil karena kelembaban tanah juga mengalami peningkatan.

\section{Laju Infiltrasi Pada Setiap Sampel Massa Akar Vegetasi}

Laju infiltrasi dan berat akar vegetasi sangat berhubungan dalam penentuan kebutahan air tanah. Hal ini dapat dilihat setelah dilakukan pengujian infiltrasi serta penentuan berat akar vegetasi yang dihubungkan berdasarkan data yang diperoleh dengan metode $R$ squared polynomial. Hasil pengujian infiltrasi dapat dilihat pada Gambar 4.

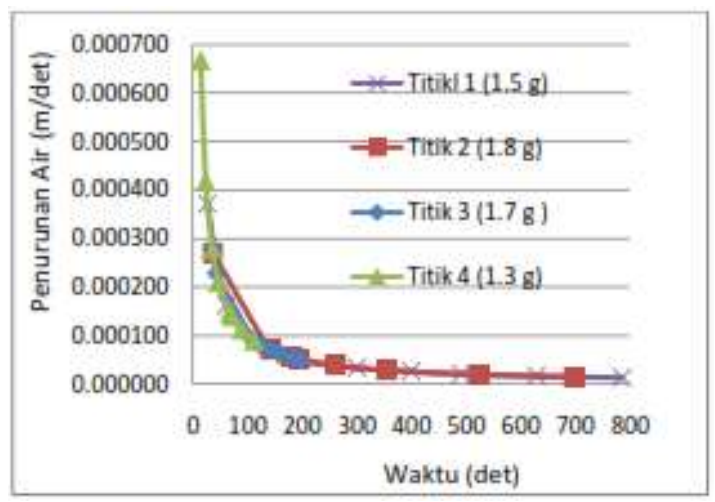

Gambar 4. Laju infiltrasi pada setiap sampel massa akar vegetasi

Pengukuran infiltrasi dilakukan
dengan metode langsung, dengan menggunakan doubel ring. Pengambilan sampel ini menggunakan lahan percobaan yang sama akan tetapi titik pengambilan sampel berbeda yang ditinjau dari penutupan lahan yang ada atau vegetasi yang terdapat diatas titik pengambilan sampel. Setiap pembacaan penurunan air ke tanah dihitung dengan interval waktu penurunan masuknya air kedalam tanah setiap $1 \mathrm{~cm}$ dalam pembacaan 8 kali setiap sampel dengan menggunakan meteran. Pada sampel I dan sampel IV memiliki penurunan air yang cukup lama dibandingkan dengan sampel II dan sampel III dapat dilihat pada kurvalaju infiltrasi yang menjelaskan setiap sampel memiliki interval waktupenurunan yang berbeda. Hal ini dipengaruhi oleh beberapa faktor 
yang dapat mempengaruhi terjadinya proses laju infiltrasi diantaranya, yaitu vegetasi, dan tekstur tanah. Hal ini sesuai pendapat Rahim (2013) bahwa faktorfaktor yang mempengaruhi laju infiltrasi adalah tekstur tanah, kadar air tanah dan vegetasi. Jika di hubungkan antara data lajuinfiltrasi denga berat akar vegetasi maka dapat dilihat bahwa akar vegetasi memberi pengaruh besar terhadap laju infiltrasi. Vegetasi atau penutupan lahanyang dipilih saat pengambilan sampel merupakan tanaman yang baik yang dilihat dari kepadatan tanaman tersebut, selain membantu

proses infiltrasi vegetasi juga memberi pengaruh topografi terhadap erosi. Hal ini sesuai pendapat Rahim (2013) bahwa adanya vegetasi penutup tanaman yang baik, seperti rumput yang tebal dan hutan yang lebat dapat menghilangkan pengaruh topografi terhadap erosi. Maka dari itu vegetasi sangat dibutuhkan dalam proses pertambahan air tanah dimana akar vegetasi memberi pengaruh terhadap proses penyerapan air atau penerus air ke dalam tanah. sehingga dapat dilihat pengaruh vegetasi terhadap laju infiltrasi. Oleh kerena itu, data pengukuran laju infiltrasi dan berat akar vegetasi memiliki hubungan yang sama atau berbanding lurus, semakin berat akar vegetasi maka laju infiltrasi semakin cepat terjadi. Hal ini sesuai pendapat Rahim (2013) bahwa bila ditinjau darisudut vegetasi maka semakin besar penetrasi akar, maka laju infiltrasi akan semakin besar.

\section{PENUTUP}

\section{Kesimpulan}

Kesimpulan yang didapat dari penelitian ini adalah:

1. Tekstur tanah pada hasil penelitian termasuk tekstur berpasir dan lempung berpasir.

2. Berat akar vegetasi mempengaruhi laju infiltrasi sehingga volume air tanah meningkat.
3. Kadar air tanah yang terkandung pada setiap titik lokasi berbanding lurus dengan berat akar vegetasi, dan laju infiltrasi.

\section{DAFTAR PUSTAKA}

Agung B, Supangat, Pamungkas B. dan Putra. 2010. Infiltrasi Tanah Pada Berbagai Tegakan Jati. Balai Penelitian Hutan Penghasil Serat Kuok. Jl. Raya Bangkinang - Kuok Km. 9 Bangkinang 28401, Kotak Pos 4/BKN - Riau. Jawa Tengah.

Arifin.Moch.2010. Kajian Sifat fisik tanah dan Berbagai Penggunaan Lahan Dalam Hubungannya Dengan Pendugaan Erosi Tanah.

Elsa Rosyidah dan Ruslan Wirosoedarmo. 2013. Pengaruh Sifat Fisik Tanah Pada Konduktivitas Hidrolik Jenuh Di 5 Penggunaan Lahan (Studi Kasus Di Kelurahan Sumbersari Malang). Jurusan Keteknikan Pertanian, Fakultas Teknologi Pertanian, Universitas Brawijaya. Jl. Veteran. Malang.

Hakim N, Yusuf N, Am Lubis, dan Sutopo GN, M Amin D, Go BH, HH Bailley. 2000. Dasar-dasar Ilmu Tanah. Lampung: Universitas Lampung.

Jati Kuncoro Munaljid. 2015. Aplikasi Model Infiltrasi Pada Tanah Dengan Model Kostiyacov dan Model Horton Menggunakan Alat Rainfall Simulator. Kementerian Riset Teknologi Dan Pendidikan Tinggi Universitas Brawijaya. Fakultas Teknik. Malang.

Rahim, S. E. 2013. Pengendalian Erosi Tanah: Dalam Rangka Pelestarian Lingkungan Hidup. Bumi Aksara. Jakarta

Suharto, E., 2006. Kapasitas Simpan Air Tanah Pada Sistem Tata Guna Lahan LPP Tahura Raja Lelo, Jurnal Ilmuilmu Pertanian Indonesia, Volume 8.No. 1, Hlm. 44-49 ISSN 1441-0067, Bengkulu. 